\title{
Orbiculoidea baini and Orbiculoidea excentrica (Brachiopoda, Discinidae) from the Middle Devonian (Alto Garças Sub-basin, Paraná Basin) of Caiapônia, Goiás (Brazil) Orbiculoidea baini e Orbiculoidea excentrica (Brachiopoda, Discinidae) do Devoniano Médio (Sub-bacia Alto Garças, Bacia do Paraná) de Caiapônia, Goiás (Brasil)
}

\author{
Fábio Augusto Carbonaro ${ }^{1}$ (D), Jeanninny Carla Comniskey² ${ }^{\text {(D) }}$, Heloísa Stok Corral ${ }^{1}$ (D), Renato Pirani Ghilardi ${ }^{1}$ \\ 'Departamento de Ciências Biológicas, Faculdade de Ciências de Bauru, Universidade Estadual Paulista "Júlio de \\ Mesquita Filho" - UNESP, Avenida Engenheiro Luiz Edmundo Carrijo Coube, 14-01, CEP 17033-360, Bauru, SP, BR \\ (fabiocarbonaro@yahoo.com.br; heloisastock@hotmail.com; ghilardi@fc.unesp.br) \\ 2Programa de Pós-graduação em Geografia, Universidade Estadual de Ponta Grossa - UEPG, Ponta Grossa, PR, BR \\ (comniskey@gmail.com)
}

Received on September 11, 2017; accepted on September 20, 2018

\begin{abstract}
The Devonian brachiopods from Goiás (Alto Garças Sub-basin, Paraná Basin) present records in the cities of Caiapônia, Amorinópolis, and Doverlândia. However, most of the papers only mention the presence of these fossils in these areas, without any taxonomic description. Thus, our aim was to describe the discinoids Orbiculoidea baini, Orbiculoidea excentrica, and Orbiculoidea sp. found in Caiapônia city. These discinoids were preserved in assemblage, instigating a simplified taphonomic approach. The fossils were found parallel to bedding planes in a poorly package assemblage. Most of them are entire and unarticulated. Although in smaller numbers, several fragmented individuals were also found (some quite fragmented). Therefore, the material was transported configuring a parautochthonous to allochthonous taphocenosis. Another interesting aspect is the decreased size of the brachiopods, which were preserved in sandstone lens on the top of a siltstone layer that overlap black shales of the Early Givetian age. These features can be related to the Lilliput Effect, due to the preserved discinoids present both in adult and juvenile forms. The Lilliput Effect resulted from a biotic crisis (KAČÁK Event) that occurred in the Eifelian-Givetian. This is the first piece of evidence of this effect in the Devonian of Goiás (Alto Garças Sub-basin, Paraná Basin).
\end{abstract}

Keywords: Chapada Group Unit 4; Early Givetian; Invertebrates; KAČÁK Event; Malvinokaffric fauna.

\begin{abstract}
Resumo
Os braquiópodes devonianos de Goiás (Sub-bacia Alto Garças, Bacia do Paraná) possuem registros nos municípios de Caiapônia, Amorinópolis e Doverlândia. No entanto, a maior parte dos trabalhos existentes sobre esse grupo apenas cita a ocorrência desses fósseis nessas áreas, sem qualquer descrição taxonômica. Em vista disso, o objetivo do presente trabalho foi descrever os discinídeos Orbiculoidea baini, Orbiculoidea excentrica e Orbiculoidea sp. encontrados na cidade de Caiapônia. Tais braquiópodes foram preservados em assembleia nesse afloramento, instigando uma abordagem tafonômica simplificada. Os fósseis foram encontrados paralelos ao plano de acamamento, em uma assembleia fracamente empacotada com espécimes, em sua maioria, inteiros e inarticulados. Embora em menor número, vários indivíduos fragmentados também foram encontrados (alguns estilhaçados), o que reflete em transporte do material antes do soterramento, configurando uma tafocenose parautóctone a alóctone. Outro aspecto interessante é o tamanho diminuto dos braquiópodes associado ao fato de estes terem sido preservados em uma lente arenítica no topo de um siltito localizado sobre folhelhos pretos de idade Eogivetiana. Essas características podem estar relacionadas ao Efeito Lilliput, em virtude de os discinídeos preservados constituírem tanto formas adultas quanto juvenis. O Efeito Lilliput resultou de uma crise biótica (evento KAČÁK) ocorrida durante o Eifeliano-Givetiano. Essa é a primeira evidência desse efeito no Devoniano de Goiás (Sub-bacia Alto Garças, Bacia do Paraná).
\end{abstract}

Palavras-chave: Unidade 4 do Grupo Chapada; Eogivetiano; Invertebrados; Evento KAČÁK; Fauna Malvinocáfrica. 


\section{INTRODUCTION}

Several Devonian fossils are found in Goiás, such as brachiopods, molluscs, crinoids, trilobites, annelids, tentaculitids, chitinozoans, and lycophytes. These materials are recorded in the cities of Caiapônia, Iporá, Amorinópolis, Doverlândia, and Rio Verde (Carbonaro and Ghilardi, 2016). According to Carbonaro and Ghilardi (2016), brachiopods are the most representative group of these areas with records of the genus Australospirifer, Australocoelia, Derbyina, Schuchertella, Cryptonella, infaunal lingulids, Chonetes, and Orbiculoidea (Oliveira, 1937; Almeida, 1948; Andrade and Camarço, 1978, 1980; Marques, 2006; Carbonaro and Ghilardi, 2016). However, this material must be revised, because many species were only cited for the area, without accurate taxonomic description.

Despite the great diversity of brachiopods, only the genus Orbiculoidea will be emphasized. It presents wide geographical distribution in the Devonian of Paraná, Parecis, Parnaíba, and Amazonas basins (Clarke, 1913; Lange, 1943; Boucot et al., 2001; Melo, 1988). The occurrences in the Paraná Basin at Goiás (Alto Garças Sub-basin) include Orbiculoidea baini (Sharpe, 1856), Orbiculoidea excentrica (Lange, 1943), and Orbiculoidea sp. recorded in Caiapônia and Amorinópolis cities (Oliveira, 1937; Almeida, 1948; Andrade and Camarço, 1978, 1980; Marques, 2006; Carbonaro and Ghilardi, 2016). In addition, Orbiculoidea has also been recorded in Paraná (Apucarana Sub-basin, Paraná Basin), where were found $O$. baini, O. excentrica, and Orbiculoidea bodenbenderi (Clarke, 1913), besides other discinoids as Gigadiscina collis (Clarke, 1913) and ?Rugadiscina sp. (Comniskey et al., 2016). In order to formalize the taxonomic classification of the records from Caiapônia outcrop (Goiás, Brazil), indicated in Carbonaro and Ghilardi (2016), the species Orbiculoidea baini and Orbiculoidea excentrica are described herein. Furthermore, taphonomic considerations are also presented.

The Caiapônia outcrop was previously studied by Carvalho et al. (1987), that described some trilobites of the genus Metacryphaeus for the area. However, in our fieldwork, brachiopods and phytofossils were found in great number. The same outcrop was called GO 15 in the works of Carbonaro and Ghilardi (2016) and Grahn et al. (2016). Furthermore, Grahn et al. (2016) dated these rocks through the acritarch Duvernaysphaera angelae (Deunff, 1964) and chitinozoans Alpenachitina eisenacki (Dunn and Miller, 1964), ?Ancyrochitina flexuosa (Burjack, 1996), and Eisenackitina aranea (Urban, 1972) indicating Early Givetian age, which corresponds to Chapada Group Unit 4.

The outcrop age and the discinoids characteristics may indicate the occurrence of the Lilliput Effect in the area. It resulted from a biotic crisis of global proportions occurred in the Eifelian-Givetian, called KAČÁK Event. This global event is related to a period of anoxia (or dysoxia) of the ocean floor. Furthermore, it is represented in the geological records as extensive black shales deposited in marine environments (House, 1989, 1996, 2002).

The Lilliput Effect caused a drastic decrease in the size of organisms as a result of an environmental disturbance (Urbanek, 1993). This effect was previously identified in the Paraná Basin in the works of Bosetti et al. (2010, 2011) and Horodyski (2014). However, these records are related to the Apucarana Sub-basin.

The discinoids records in the Paraná Basin span from the Pragian to the Givetian. However, the Eifelian-Givetian is marked by reductions in richness and abundance of these organisms (Bosetti et al., 2010; Horodyski, 2010; Comniskey, 2011; Bosetti et al., 2012; Horodyski, 2014; Comniskey et al., 2016). Only $O$. excentrica and $O$. baini are recorded in the Givetian of the Apucarana Sub-basin (Paraná Basin; Comniskey et al., 2016). The causes of these richness and abundance reductions regard the Malvinokaffric decline and the KAČÁK Event (House, 2002; Bosetti et al., 2010, 2011, 2012; Horodyski, 2014; Horodyski et al., 2014).

\section{GEOLOGICAL SETTING}

The Paraná Basin covers several Brazilian states, such as Rio Grande do Sul, Santa Catarina, Paraná, São Paulo, Minas Gerais, Goiás, Mato Grosso and Mato Grosso do Sul, as well as other countries like Argentina, Paraguay and Uruguay, totaling around $1.600 .000 \mathrm{~km}^{2}$ in South America (Petri and Fulfaro, 1988; Melo, 1988; Milani et al., 2007).

During the Devonian, two sub-basins were deposited in the Paraná Basin: Alto Garças in the North and Apucarana in the South, which were separated by Três Lagoas and Campo Grande highs (Ramos, 1970). These strata are characterized by sedimentary successions related to transgressive-regressive marine cycles (Milani et al., 2007).

The fossils of the present work are from the Alto Garças Sub-basin, which is subdivided into Chapada Group units 1, 2, 3, and 4 (Melo, 1988; Grahn et al., 2010). The Unit 4 is the focus of this study, because it presents black shales with intercalations of clay and silty sandstones. The upper contact of the Unit 4 is erosive and occurs with the diamictites of the Itararé Group (Carboniferous; Andrade and Camarço, 1980; Grahn et al., 2010). This unit is coeval to the São Domingos Formation of the Apucarana Sub-basin (Melo, 1988) and the beginning of its deposition is related to the maximum marine transgression occurred at the Early Givetian (Assine, 2001; Grahn et al., 2010). According to Grahn et al. (2010), the rocks of this unit have GivetianEarly Frasnian age. 


\section{MATERIALS AND METHODS}

The fossil material was collected in the GO 15 outcrop $\left(51^{\circ} 46^{\prime} 48,022^{\prime \prime} \mathrm{O}, 16^{\circ} 50^{\prime} 40,059^{\prime \prime} \mathrm{S}\right.$; Figure 1), located in Caiapônia city (Goiás, Brazil), also known as "Ribeirão do Monte" by Carvalho et al. (1987). This material is deposited in the scientific collection of the Laboratório de Paleontologia de Macroinvertebrados (CCLP) localized at Unesp-Bauru (São Paulo, Brazil) with the numbers: CCLP 875 to 911,946 to 983,985 to 998,1000 to 1002,1118 , and 1119. It is noteworthy that these 97 numbered samples contain about 317 discinoids specimens. Each sample is a portion of the taphocenosis composed of many small size individuals $(1-9 \mathrm{~mm})$.

The fossils were collected from thin lens of fine sandstone (Figure 2). The morphological aspects evaluated include: width and length of the valves $(\mathrm{mm})$; number of rugellae; number of rugellae per $2.5 \mathrm{~mm}$ of shell length; average thickness of the interspaces of the ventral and dorsal valves $(\mathrm{mm})$; ratio between the pedicle and the shell length; ratio between the anterior and posterior lengths based on the dorsal valve apex (\%). The apex displacement angle was not measured, because the fossils are flattened dorso-ventrally.

Regarding the taphonomic simplified analysis, the protocols proposed by Simões and Ghilardi (2000) and Ghilardi (2004) were adapted. As several fossiliferous levels were not identified in the GO 15 outcrop, we prefer not to use the quadricules method. All the samples collected were geographically oriented in order to evaluate the bioclasts arrangement in the sedimentary matrix. For the analysis, the discinoid taphocenosis was evaluated for: number of articulated and disarticulated individuals; number of complete and fragmented valves; number of ventral and dorsal valves; azimuthal distribution; and number of individuals of each species.

\section{SYSTEMATIC PALAEONTOLOGY}

Class Lingulata (Gorjansky and Popov, 1985)

Order Lingulida (Waagen, 1885)

Superfamily Discinoidea (Gray, 1840)

Family Discinidae (Gray, 1840)

Subfamily Orbiculoideinae (Schuchert and LeVene, 1929)

Genus Orbiculoidea (d'Orbigny, 1847)

Type species: Orbicula forbesii (Davidson, 1848)

Orbiculoidea baini (Sharpe, 1856) (Figures 3A and 3B).

Orbicula bainii (Sharpe, 1856), p. 210, pl. 26, fig. 20-23.

Orbiculoidea baini (Reed, 1903), p.168, pl. 20, fig. 4-5.

Orbiculoidea baini (Clarke, 1913), p. 301, pl. 25, fig. 5-15.

Orbiculoidea baini (Kozlowski, 1913), p. 8-108, pl. 1, fig. 11-13.

Orbiculoidea (Roemerella) baini (Reed, 1925), p. 36-38.

Orbiculoidea baini (Melo, 1985), p. 48-57, fig. 1-2.

Orbiculoidea baini (Figueiras, 1991), p. 57-64.

Orbiculoidea falklandensis (Boucot et al., 2001), p. 111, pl. 2, fig. 1-17.

Orbiculoidea baini (Comniskey, 2011), p. 182, pl. 4-7.

\section{Materials}

CCLP 876, CCLP 879, CCLP 880, CCLP 881, CCLP 882, CCLP 884, CCLP 885, CCLP 886, CCLP 889, CCLP 890,

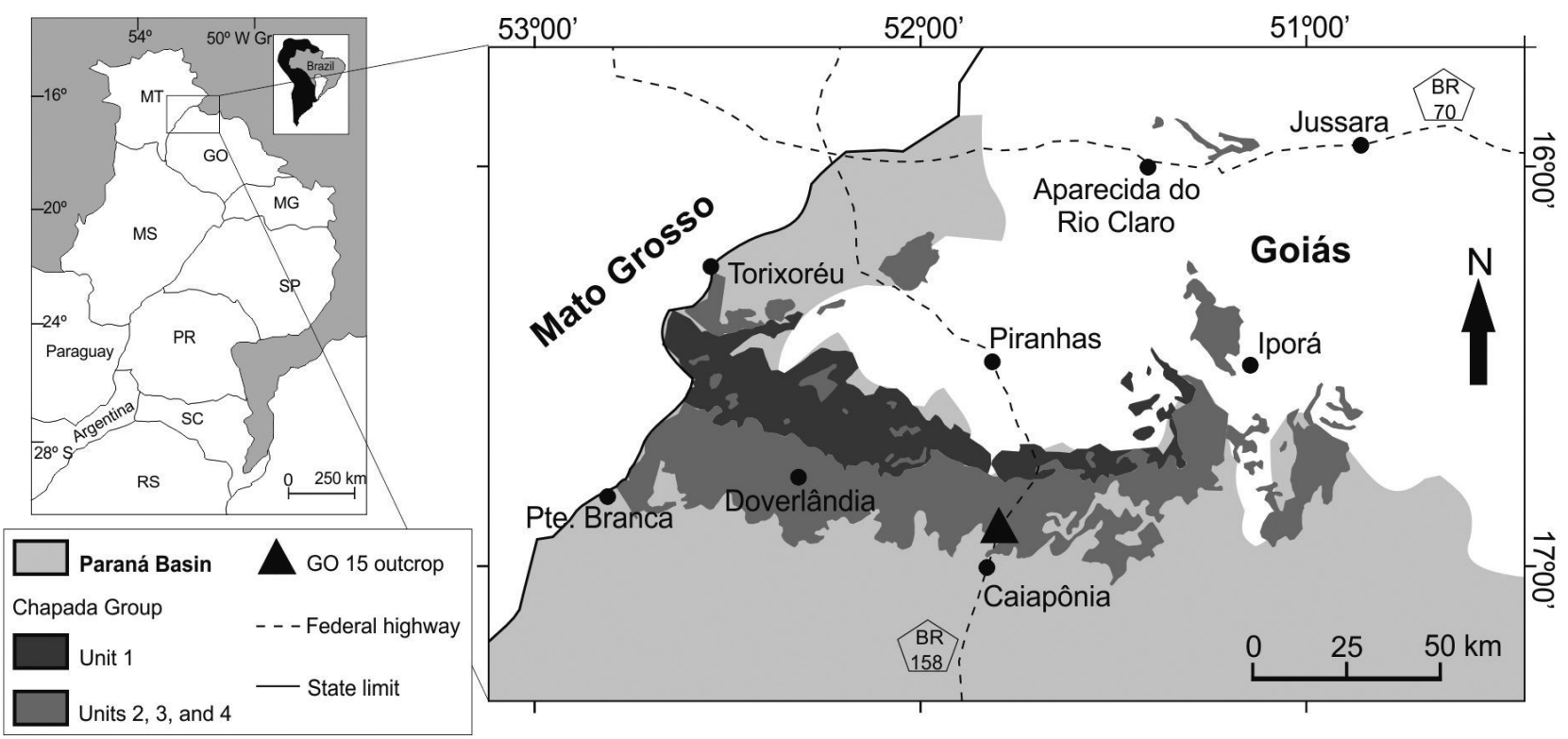

Figure 1. Location map of the GO 15 outcrop ( $\left.51^{\circ} 46^{\prime} 48,022^{\prime \prime} \mathrm{O}, 16^{\circ} 50^{\prime} 40,059^{\prime \prime}\right)$ ). 


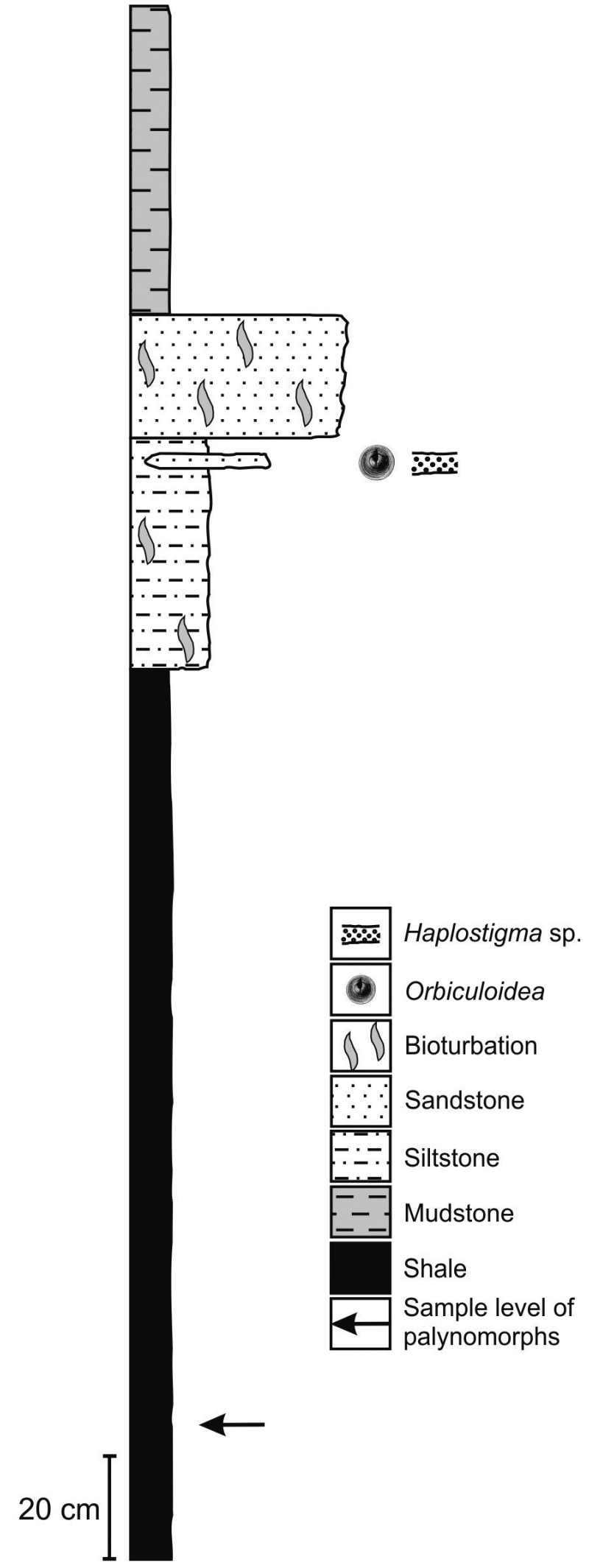

Figure 2. Columnar profile of the GO 15 outcrop (Chapada Group Unit 4, Early Givetian).
CCLP 900, CCLP 909, CCLP 947, CCLP 948, CCLP 951, CCLP 952, CCLP 971, CCLP 976, CCLP 980, CCLP 981, CCLP 982, CCLP 987, CCLP 994 and CCLP 1118. Totalizing about 15 ventral valves, 8 dorsal valves, and 9 undefined.

Chronostratigraphic distribution

Late Praguian - Early Givetian.

Geographic distribution

Ponta Grossa, Tibagi and Jaguariaíva cities in Paraná, and Caiapônia city in Goiás.

\section{Description}

Subcircular shells with width greater than the length. The brachiopods present reduced size, about 3-7 mm of length and 3-8 mm of width. Some fossils have about $1 \mathrm{~mm}$ of length and only four rugellae, which qualify them as juvenile forms. Elevated rugellae are disposed concentrically around the apex, which is positioned at the central portion of the shell. The number of rugellae is $7-11$ on average. The thickness average of the rugellae is $0.015-0.030 \mathrm{~mm}$ on the dorsal valve. The average of the dorsal valve interspaces is $0.17 \mathrm{~mm}$. The number of rugellae per $2.5 \mathrm{~mm}$ of dorsal valve area is around 9 to 11 . The distance from the apex to the posterior margin of the dorsal valve is about 30 to $40 \%$ of the dorsal valve total length. Therefore, the distance from the apex to the anterior margin of the shell corresponds to $60-70 \%$ of the total length. The average thickness of rugellae on the ventral valve is $0.020-0.045 \mathrm{~mm}$. The number of rugellae on the ventral valve is, on average, 7 to 13 . The ventral valve interspaces have an average size of $0.25 \mathrm{~mm}$. The pedicular notch extends from the posterior margin of the ventral valve to the apex, occupying half of the valve. The pedicular notch length varies from 1.5 to $3.0 \mathrm{~mm}$. The number of rugellae per $2.5 \mathrm{~mm}$ of the ventral valve area is 6 to 11 .

\section{Remarks}

O. baini was identified in the Middle Devonian of the Alto Garças Sub-basin (Paraná Basin) due to the circular shape of the valves, well-marked and concentric rugellae (in relation to the apex position), and centralized apex. These characteristics and the Early Givetian age of GO 15 outcrop support the taxonomic classification of the fossils. Only the discinoids $O$. baini and $O$. excentrica have records in the Givetian of the Paraná Basin, but the age factor has a lower impact than the morphological aspects.

The interspaces of $O$. baini are larger than $O$. excentrica. The apex position also differs $O$. baini from $O$. excentrica. It is more central in $O$. baini (distance of the apex 


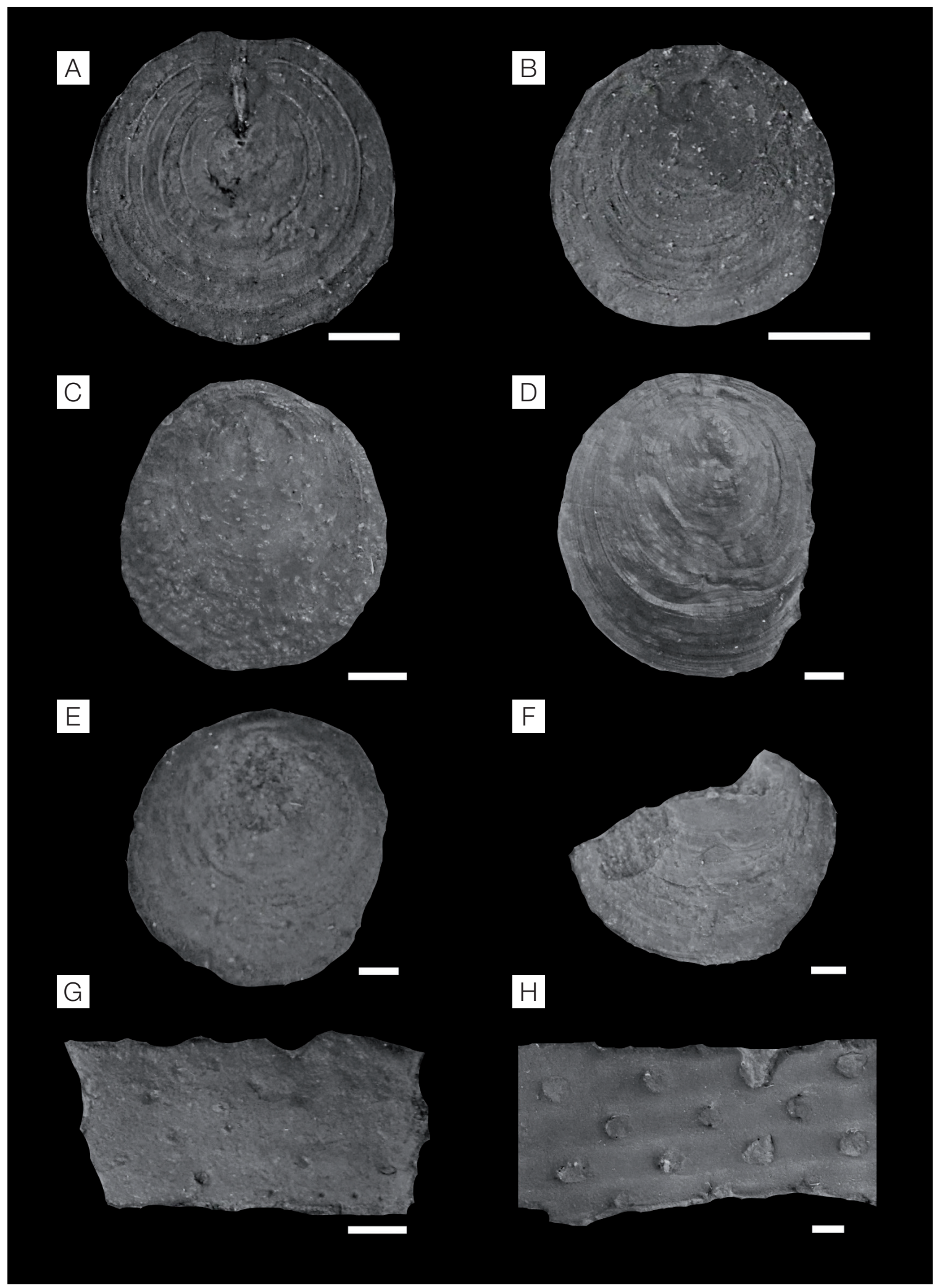

Figure 3. Discinoids and phytofossils found in the GO 15 outcrop. (A and B), Orbiculoidea baini, ventral (A; CCLP 880; external mold) and dorsal (B; CCLP 886; external mold) valves; (C and D), Orbiculoidea excentrica, ventral (C; CCLP 962; external mold) and dorsal (D; CCLP 973; external mold) valves; (E and F), Orbiculoidea sp. (CCLP 989 and 990 ; external molds); (G) ?Palaeostigma sp. (CCLP 877); (H) Haplostigma sp. (CCLP 883). Scale: (A-F) $1 \mathrm{~mm}$; (G and H) 2 mm. 
to the posterior margin is 30 to $40 \%$ of the valve total length) and more marginal in $O$. excentrica (distance of the apex to the posterior margin is 10 to $20 \%$ of the valve total length). The $O$. baini interspaces are concentric and more regular in size if compared to $O$. excentrica.

The analyzed specimens are smaller in size than the records of the Apucarana Sub-basin (Paraná Basin), which can reach up to $29 \mathrm{~mm}$ in width (Comniskey, 2011).

\section{Orbiculoidea excentrica Lange, 1943 (Figures 3C and 3D).}

Orbiculoidea excentrica (Lange, 1943), p. 223, pl. 17, p. 1. Orbiculoidea excentrica (Melo, 1985), p. 61, p. 1.

Orbiculoidea excentrica (Comniskey, 2011), p. 180, pl. 11.

\section{Materials}

CCLP 875, CCLP 876, CCLP 877, CCLP 878, CCLP 879, CCLP 884, CCLP 886, CCLP 887, CCLP 890, CCLP 892, CCLP 894, CCLP 897, CCLP 901, CCLP 903, CCLP 905, CCLP 909, CCLP 952, CCLP 953, CCLP 957, CCLP 959, CCLP 961, CCLP 962, CCLP 966, CCLP 967, CCLP 968, CCLP 970, CCLP 971, CCLP 973, CCLP 974, CCLP 980, CCLP 985, CCLP 989, CCLP 991, CCLP 993, CCLP 994, CCLP 997, CCLP 998 and CCLP 1000. Totalizing about 5 ventral valves, 44 dorsal valves, and 17 undefined.

\section{Chronostratigraphic distribution}

Late Praguian - Early Givetian.

\section{Geographic distribution}

Ponta Grossa, Tibagi, and Jaguariaíva cities in Paraná, and Caiapônia in Goiás.

\section{Description}

Oval-shaped shell. Specimens with reduced size, about $1.5-8.5 \mathrm{~mm}$ of length and $1.5-9.0 \mathrm{~mm}$ of width. Presence from 6 to 23 rugellae on the dorsal valve. The thickness average of rugellae is $0.025-0.060 \mathrm{~mm}$ on the dorsal valve. The number of rugellae per $2.5 \mathrm{~mm}$ of dorsal valve area is 12 to 18 . The average size of the interspaces is $0.26 \mathrm{~mm}$. The interspaces are smaller in the posterior region of the shell (posterior to the apex), and become wider towards the anterior portion of the valve. The distance of the apex to the posterior margin of the dorsal valve is $10-20 \%$ of the valve total length. Therefore, the distance from the apex to the anterior margin of the dorsal valve corresponds to $80-90 \%$ of the valve length. Few ventral valves were found, but the pedicle slit was short $(0.88-1.63 \mathrm{~mm})$. The apex is located near the posterior margin of the shell. The thickness average of the rugellae on the ventral valve is 0.040 $0.055 \mathrm{~mm}$. The number of rugellae on the ventral valve is 8 to 22 . The average size of the interspaces of the ventral valve is $0.23 \mathrm{~mm}$. The number of rugellae per $2.5 \mathrm{~mm}$ of ventral valve area is 12 to 16 .

\section{Remarks}

The main characteristics that led to the identification of $O$. excentrica in the GO 15 outcrop (Early Givetian age) are related to: the valve oval shape; the proximity between the rugellae and apex position, which is close to the posterior margin in this species; and the age of rocks, since the only species of the genus Orbiculoidea with records in the Givetian of the Paraná Basin are O. baini and $O$. excentrica.

Orbiculoidea excentrica differs from Orbiculoidea baini due to the size of the interspaces (proportionally smaller in Orbiculoidea excentrica), more marginal position of the apex, and less marked rugellae.

All $O$. excentrica analyzed specimens present reduced size when compared to the Apucarana Sub-basin specimens, which can reach up to $23 \mathrm{~mm}$ of width (see Comniskey, 2011).

\section{Orbiculoidea sp. (Figures 3E and 3F)}

\section{Materials}

CCLP 883, CCLP 888, CCLP 890, CCLP 891, CCLP 892, CCLP 893, CCLP 896, CCLP 898, CCLP 904, CCLP 906, CCLP 908, CCLP 947, CCLP 948, CCLP 949, CCLP 950, CCLP 951, CCLP 953, CCLP 954, CCLP 955, CCLP 958, CCLP 961, CCLP 964, CCLP 969, CCLP 975, CCLP 977, CCLP 988, CCLP 989, CCLP 990, CCLP 1001 and CCLP 1002. Totalizing about 15 dorsal valves and 172 undefined.

\section{Chronostratigraphic distribution}

Early Givetian.

\section{Geographic distribution}

Caiapônia (Goiás, Brazil).

\section{Description}

Subcircular shell. Valves with 3 to $8 \mathrm{~mm}$ of length and width. Dorsal valves flattened dorso-ventrally. The rugellae could be counted in only three specimens (CCLP 893, CCLP 896 and CCLP 1001), which had 10 to 12 rugellae. 


\section{Remarks}

This material could not be identified because the specimens are fragmented, the rugellae are poorly preserved, and the apex is fragmented. However, these fossils were found associated with the species $O$. baini and $O$. excentrica, which reinforces its identification as belonging to the genus Orbiculoidea. In this fossil assemblage, only these brachiopods (O. baini, O. excentrica, and Orbiculoidea sp.) and few plants of the genus Haplostigma and ?Palaeostigma were identified (Figures $3 \mathrm{G}$ and $3 \mathrm{H}$ ). Considering the outcrop age, these specimens probably belong to the species $O$. baini and O. excentrica, because they are the unique Orbiculoidea species that have been recorded in the Givetian of the Paraná Basin. However, due to the poor preservation state of the material, it is preferred to classify it here as Orbiculoidea sp.

\section{TAPHONOMIC CONSIDERATIONS}

Among the 317 brachiopod collected molds, only one specimen exhibited articulated valves. Most of the valves are complete $(n=168)$, while 71 are fragmented due to the transport of these bioclasts, and 78 were fragmented during the collection and discarded for the taphonomic analysis.

The dorsal valves are flattened dorso-ventrally due to preservational conditions. The number of dorsal valves $(n=79)$ is higher than ventral valves $(\mathrm{n}=20)$, and Orbiculoidea excentrica presented more preserved specimens (about 66) than Orbiculoidea baini (32 specimens). However, most of the material was classified as Orbiculoidea $\mathrm{sp} .(\mathrm{n}=187)$, while 32 specimens could not be properly identified because they were poorly preserved (Figure 4). The azimuthal distribution could only be evaluated in 55 specimens of Orbiculoidea excentrica, Orbiculoidea baini, and Orbiculoidea sp. present in the taphocenosis.

The material was found in the horizontal position according to the bedding plane, thus configuring a weak package assemblage. Most of the valves are complete and disarticulated. Some valves are fragmented (some of them are quite fragmented). These characteristics indicate transport of the bioclasts prior to burial, configuring a parautochthonous to allochthonous assemblage. It is worth mentioning that the predominance of the entire valves, deposited according to the bedding plane, reflects in transportation under suspension and decantation of the individuals before the bioclasts burial. The horizontal orientation of the bioclasts is polymodal, which means that there is no preferential orientation of the bioclasts (Figure 5).

Most of the brachiopod valves are disarticulated and parallel to the bedding plane. This pattern suggests the presence of a time interval between the death of these organisms and their final burial, without hydrodynamic selection (fossils with 1 to $9 \mathrm{~mm}$ of length/width).
Some phytofossils were found associated with the discinoids of the GO 15 outcrop (Figures $3 \mathrm{G}$ and $3 \mathrm{H}$ ). They were identified as Haplostigma sp., ?Palaeostigma sp. (CCLP 878, $882,883,954,958,962,982,983$, and 984), and fragmented plants (CCLP 879, 880, 882, 884, 885, 886, 890, 891, 893, 900, 950, 963, 970, 972, 973, 976, 980, 988, 989 and 993). This indicates a polytypic and polyspecific taphocenosis.

The taphonomic signatures identified here are similar to that presented in the B2 subclass (individuals with complete or fragmented disarticulated valves) of Comniskey et al. (2016) presented for the Apucarana Sub-basin. This subclass is associated with offshore-transitional deposits. The discinoids were found in sandstone lens located on the top of a siltstone layer. This may indicate a transitional offshore deposit.

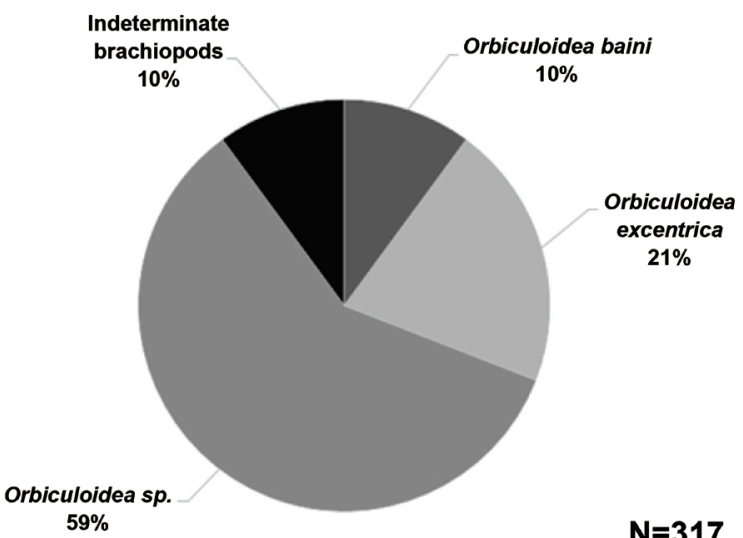

Figure 4. Percentage of discinoids found in the GO 15 outcrop.

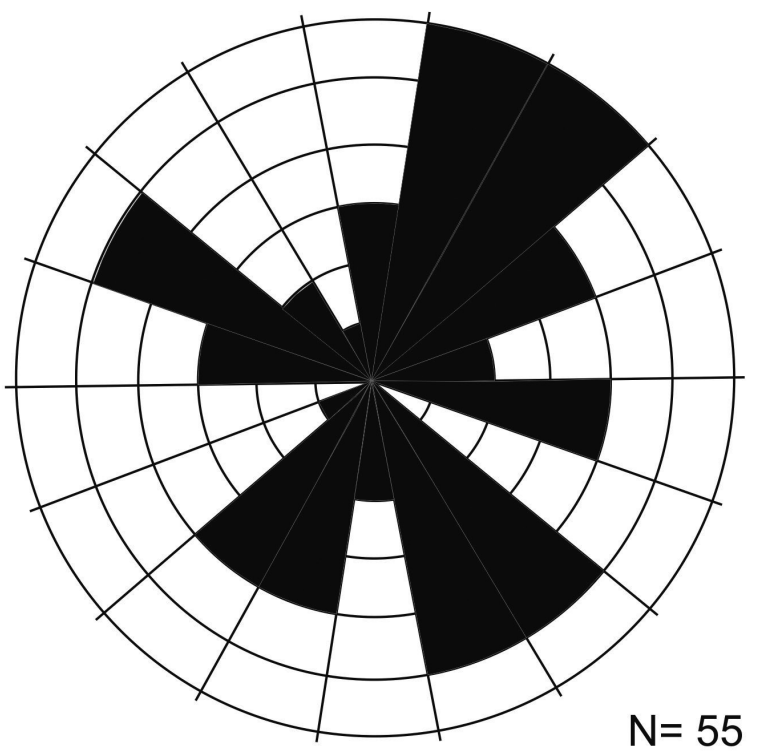

$\mathrm{N}=$ number of specimens of the genus Orbiculoidea

Figure 5. Orientation rose-diagram of body axes in discinoids found at the GO 15 outcrop. 
The small size of the individuals (1 to $9 \mathrm{~mm}$ of length/ width) could be related to the Lilliput Effect, which has already been verified for the Apucarana Sub-basin (Bosetti et al., 2010, 2011), because there are records of juvenile and adult forms with reduced size.

\section{LILLIPUT EFFECT}

The Lilliput Effect was identified in the area because of the Early Givetian age of the black shales found in the GO 15 outcrop (Figure 2 ) and the variable size of the brachiopods with different number of rugellae.

The lithofacies of the GO 15 outcrop present basal black shales of Early Givetian age (without records of macrofossils and bioturbation) overlapped by bioturbated siltstones and sandstones, indicating a transgressive system on the base followed by a regression (Figure 2). These black shales are probably related to the maximum transgression, which occurred during the Eifelian-Givetian, and to the KAČÁK Event.

The fauna of subnormal size phenotypes is usually found after the records of the black shales of Late Eifelian-Early Givetian age, being present in the GO 15 outcrop with the occurrences of $O$. baini, O. excentrica, and Orbiculoidea sp. According to Bosetti et al. (2011), these species showed a reduction of up to $90 \%$ in the body size after the KAČ́ÁK Event. The length of a normal adult is about 18 to $32 \mathrm{~mm}$ (Bosetti et al., 2011), and the fossils found present 1 to $9 \mathrm{~mm}$ of length/width.

On the other hand, the presence of reduced size adults can also be related to selective death events, such as diseases, aging and/or predation that affect more young and old individuals. However, there are morpho-anatomical pieces of evidence that the discinoids are at different ontogenetic stages (early and intermediate), mainly due to the number of rugellae (6-23 on O. excentrica and 7-13 on O. baini).

The morpho-anatomical evidence added to lithological and palynological characteristics support the interpretation of subnormal phenotype as a result of the KAČÁK Event. This record is unprecedented for the Alto Garças Sub-basin (Paraná Basin).

\section{FINAL CONSIDERATIONS}

This study presents, for the first time, a formal taxonomic description for the discinoids of the Alto Garças Sub-basin found in Goiás. Prior to it, only the presence of these fossils was indicated for the area (Oliveira, 1937; Almeida, 1948; Andrade and Camarço, 1978, 1980; Marques, 2006; Carbonaro and Ghilardi, 2016). These discinoids were collected in Caiapônia surroundings and were identified as Orbiculoidea baini, Orbiculoidea excentrica, and Orbiculoidea sp.

Most of the fossils were found entire, disarticulated and parallel to the bedding plane, indicating that the bioclasts had been transported under suspension and deposited on the ocean floor before the burial. This configures a parautochthonous to allochthonous taphocenosis. There was probably no selective death, due to the presence of fossils with different ontogenetic stages (juveniles and adults).

The probable pieces of evidence to the occurrence of the Lilliput Effect in the GO 15 outcrop are: black shales with Duvernaysphaera angelae, Alpenachitina eisenacki, ?Ancyrochitina flexuosa and Eisenackitina aranea that indicate Early Givetian age for the basal layer of the outcrop (Grahn et al., 2016); and the taphocenosis with juvenile and adult individuals of the genus Orbiculoidea with reduced sizes (1-9 mm). This interpretation is inedited for the Alto Garças Sub-basin and still needs to be better investigated through more fieldwork in the Devonian of Goiás State, which is still largely neglected in the literature.

\section{ACKNOWLEDGMENTS}

F. A. Carbonaro and H. S. Corral thank Fundação de Amparo à Pesquisa do Estado de São Paulo (FAPESP, 2013/09683-3 and 2016/08937-0). F. A. Carbonaro thanks Débora Gomes and Bruno S. Francisco for their help with the taphonomy analysis and for their collaboration regarding field work in Goiás (Brazil), respectively.

\section{REFERENCES}

Almeida, F. F. M. (1948). Contribuição à geologia dos Estados de Goiás e Mato Grosso. Notas Preliminares e Estudos da Divisão de Geologia e Mineralogia do DNPM, 46, 1-17.

Andrade, S. M., Camarço, P. E. N. (1978). Mapeamento Geológico a Leste das Cidades de Iporá - Amorinópolis. Relatório Final. Goiânia: Nuclebrás. 32 p.

Andrade, S. M., Camarço, P. E. N. (1980). Estratigrafia dos sedimentos devonianos do flanco nordeste da Bacia do Paraná. XXXI Congresso Brasileiro de Geologia, 5, 2828-2834. Balneário de Camboriú: Sociedade Brasileira de Geologia.

Assine, M. L. (2001). O Ciclo Devoniano na Bacia do Paraná e correlação com outras bacias Gondwânicas. Ciência, Técnica, Petróleo, Seção Exploração de Petróleo, 20, 55-62.

Bosetti, E. P., Grahn, Y., Horodyski, R. S., Mauller, P. M. (2012). The first recorded decline of the Malvinokaffric Devonian fauna in the Paraná Basin (southern Brazil) and its cause; taphonomic and fossil evidences. Journal of South American Earth Sciences, 37, 228-241. https://doi. org/10.1016/j.jsames.2012.02.006 
Bosetti, E. P., Grahn, Y., Horodyski, R. S., Mauller, P. M., Breuer, P., Zabini, C. (2011). An earliest Givetian "Lilliput Effect" in the Paraná Basin, and the collapse of the Malvinokaffric shelly fauna. Paläontologische Zeitschrift, 85(1), 49-65. https://doi.org/10.1007/s12542-010-0075-8

Bosetti, E. P., Horodyski, R. S., Zabini, C., Matsumura, W. M. K., Penteado, A. C. (2010). Ocorrência de fenótipos subnormais no limite Neoeifeliano/Eogivetiano, Tibagi, Estado do Paraná: implicações tafonômicas e paleossinecológicas. Boletim do Museu Paraense Emilio Goeldi, série Ciências Naturais, 5(2), 135-149.

Boucot, A. J., Rowell, A. J., Racheboeuf, P. R., Pereira, E., De Melo, J. G., De Siqueira, L. P. (2001). Position of the Malvinokaffric Realm's northern boundary (Early Devonian) based on newly discovered brachiopods from the Parecis Basin (Brazil). Journal of Geosciences, 46(3-4), 109-120.

Burjack, M. I. A. (1996). Quitinozoários givetianos da Formação Ponta Grossa, Bacia do Paraná, Brasil. Boletim Goiano de Geografia, 16(1), 53-81. https://doi.org/10.5216/ bgg.v16i1.4319

Carbonaro, F. A., Ghilardi, R. P. (2016). Fósseis do Devoniano de Goiás, Brasil (Sub-bacia Alto Garças, Bacia do Paraná). Papéis Avulsos de Zoologia, 56(11), 135-149. http://dx.doi. org/10.11606/0031-1049.2016.56.11

Carvalho, M. G. P., Melo, J. H. G., Quadros, L. P. (1987). Trilobitas Devonianos do flanco noroeste da Bacia do Paraná. X Congresso Brasileiro de Paleontologia, 545-565. Rio de Janeiro: Sociedade Brasileira de Paleontologia.

Clarke, J. M. (1913). Fósseis devonianos do Paraná. Monograph. Serviço Geológico e Mineralógico do Brasil.

Comniskey, J. C. (2011). Paleontologia dos Discinidae (Brachiopoda: Linguliformea) da sucessão devoniana da Bacia do Paraná, Estado do Paraná, Brasil: revisão sistemática, distribuição geográfica e estratigráfica. Dissertação (Mestrado). Ponta Grossa: Universidade Estadual de Ponta Grossa.

Comniskey, J. C., Bosetti, E. P., Horodyski, R. S. (2016). Taphonomic aspects and the Lilliput Effect on Devonian discinoids of the Paraná Basin, Apucarana Sub-basin, Brazil. Gaea: Journal of Geoscience, 9(1), 55. https://doi. org/10.4013/gaea.2016.91.05

Davidson, T. (1848). Mémoire sur les brachiopodes du Système silurien supérieur de l'Angleterre. Bulletin de la Société géologique de France, 5, 309-374.
D’Orbigny, A. (1847). Considérations zoologiques et géologiques sur les Brachiopodes ou Palliobranches. Comptes Rendus hebdomadaires des Séances de l'Académie des Sciences, 25(7), 266-269.

Deunff, M. J.(1964). Le genre Duvernaysphaera Staplin. Grana, 5(2), 210-215. https://doi.org/10.1080/00173136409430014

Dunn, L., Miller, T. H. (1964). A distinctive chitinozoan faunule from the Alpena Limestone (Middle Devonian) of Michigan. Journal of Paleontology, 38(4), 725-728.

Figueiras, A. (1991). Fauna eodevonica del Uruguay. Revista Técnica da YPFB, 12(1), 57-64.

Ghilardi, R. P. (2004). Tafonomia comparada epaleoecologia dos macroinvertebrados (ênfase em trilobites) da Formação Ponta Grossa (Devoniano, Sub-bacia Apucarana), Estado do Paraná, Brasil. Tese (Doutorado). São Paulo: Instituto de Geociências USP. https://doi.org/10.11606/T.44.2016.tde-08012016-144025

Gorjansky, W. J., Popov, L. Y. (1985). The morphology, systematic position, and origin of inarticulate brachiopods with carbonate shells. Paleontological Journal, (3), 1-11.

Grahn, Y., Horodyski, R. S., Mauller, P. M., Bosetti, E. P., Ghilardi, R. P., Carbonaro, F. A. (2016). A marine connection between Parnaíba and Paraná Basins during the Eifelian/ Givetian transition: review and new data. Revista Brasileira de Paleontologia, 19(3), 357-366. https://doi.org/10.4072/ rbp.2016.3.01

Grahn, Y., Mauller, P. M., Pereira, E., Loboziak, S. (2010). Palynostratigraphy of the Chapada Group and its significance in the Devonian stratigraphy of the Parana Basin, south Brazil. Journal of South American Earth Sciences, 29(2), 354-370. https://doi.org/10.1016/j. jsames.2009.09.001

Gray, J. E. (1840). Synopsis of the contents of the British Museum. London: British Museum.

Horodyski, R. S. (2010). Tafonomia dos invertebrados fósseis na sequência Eifeliana-Frasniana da sucessão devoniana da sub-bacia de Apucarana, Bacia do Paraná, Tibagi-PR, Brasil. Dissertação (Mestrado). Porto Alegre: Instituto de Geociências - UFRGS.

Horodyski, R. S. (2014). Análise tafonômica, bioestratigráfica e paleoambiental dos invertebrados marinhos da Região De Tibagi-PR (Devoniano Inferior e Médio da Bacia do Paraná). Tese (Doutorado). Porto Alegre: Instituto de Geociências - UFRGS. 
Horodyski, R. S., Holz, M., Grahn, Y., Bosetti, E. P. (2014). Remarks on sequence stratigraphy and taphonomy of the Malvinokaffric shelly fauna during the KAČÁK Event in the Apucarana Sub-basin (Paraná Basin), Brazil. International Journal of Earth Sciences (Geologische Rundschau), 103(1), 367-380. https://doi.org/10.1007/s00531-013-0954-9

House, M. R. (1989). Analysis of mid-Palaeozoic extinctions. Bulletin de la Société Belge de Géologie, 98(2), 99-107.

House, M. R. (1996). The Middle Devonian KAČÁK Event. Proceedings of the Ussher Society, 9, 79-84.

House, M. R. (2002). Strength, timing, setting and cause of mid-Palaeozoic extinctions. Palaeogeography, Palaeoclimatology, Palaeoecology, 181(1-3), 5-25. https:// doi.org/10.1016/S0031-0182(01)00471-0

Kozlowski, R. (1913). Fósiles Dévoniensis de l'état de Paraná (Brésil). Annales de Paleontologie, 8(3), 1-19.

Lange, F. W. (1943). Novos Fósseis devonianos do Paraná. Arquivos do Museu Paranaense, 3, 223-225.

Marques, R. C. (2006). Taxonomia dos invertebrados da Formação Ponta Grossa (Eomesodevoniano) na borda norte da Bacia do Paraná e análise cladística de espiriferídeos basais. Dissertação (Mestrado). São Paulo: Instituto de Geociências - USP. https://doi.org/10.11606/D.44.2006. tde-09102012-085510

Melo, J. H. G. (1985). A Província Malvinocáfrica do Devoniano do Brasil - Estado atual dos conhecimentos. Dissertação (Mestrado). Rio de Janeiro: Instituto de Geociências - UFRJ.

Melo, J. H. G. (1988). The Malvinokaffric Realm in the Devonian of Brazil. In: N. J. McMillan, A. F. Embry, D. J. Glass (Eds.), Devonian of the World, 669-703. Calgary: Canadian Society of Petroleum Geologists.

Milani, E. J., Melo, J. H. G., Souza, P. A., Fernandes, L. A., França, A. B. (2007). Bacia do Paraná. Boletim de Geociências da Petrobras, 15(2), 265-287.
Oliveira, E. (1937). Fósseis devonianos de Goyaz. Notas Preliminares e Estudos da Divisão de Geologia e Mineralogia do DNPM, 15, 2-4.

Petri, S., Fulfaro, V. J. (1988). Geologia do Brasil. São Paulo: Edusp.

Ramos, A. N. (1970). Aspectos paleo-estruturais da Bacia do Paraná e sua influência na sedimentação. Boletim Técnico da Petrobras, 13(3-4), 85-93.

Reed, F. R. C. (1903). Brachiopoda from the Bokkeveld beds. South African Museum Annals, 4, 165-200.

Reed, F. R. C. (1925). Revision of the fauna of the Bokkeveld Beds. Annals of the South African Museum, 22, 27-225.

Schuchert, C., LeVene, C. M. (1929). Brachiopoda (generum et genotyporum index et bibliographia). In: J. F. Pompeckj (Ed.), Fossilium Catalogus, Animalia, 1, 1-140. Berlin: W. Junk.

Sharpe, D. (1856). Description of Palaeozoic mollusca from South Africa. Transactions of the Geological Society of London, 2(7), 206-215.

Simões, M. G., Ghilardi, R. P. (2000). Protocolo tafonômico/ paleoautoecológico como ferramenta nas análises paleossinecológicas de invertebrados: exemplos de aplicação em concentrações fossilíferas do Paleozóico da Bacia do Paraná, Brasil. Pesquisas em Geociências, 27(2), 3-13. https://doi.org/10.22456/1807-9806.20186

Urban, J. B. (1972). A reexamination of Chitinozoa from the Cedar Valley Formation of Iowa with observations on their morphology and distribution. Bulletin of American Paleontology, 275, 1-44.

Urbanek, A. (1993). Biotic crises in the history of Upper Silurian graptoloids: a palaeobiological model. Historical Biology, 7(1), 29-50. https://doi.org/10.1080/10292389309380442

Waagen, W. H. (1985). Brachiopoda. Palaeontologica Indica, 13(1), 329-770. 